\title{
Optimization of Enzyme Dilution Buffer and Reaction Buffer for Vaccinia H-1 Related Wild Enzyme Assay and Its Stability at $4^{\circ} \mathrm{C}$
}

\author{
Deegendra Khadka \\ Nepal Academy of Science and Technology, Lalitpur, Nepal \\ e-mail: deegendrakhadka@gmail.com
}

\begin{abstract}
A human dual specific phosphates (DUSP), Vaccinia H-1 related wild enzyme (VHR), dephosphorylates both phosphotyrosine and phosphoserine/phosphothreonine residue of a protein. VHR is considered as a promising therapeutic target for cancer because the cells lacking VHR are arrested at the G1-S and G2-M transitions of the cell cycle with a decreased telomerase activity. VHR being a therapeutic target for cancer is crucial to know about its stability and its assay procedure conditions. This study was conducted to verify the viability of VHR enzyme at $4^{\circ} \mathrm{C}$. Protein concentration and specific activity were calculated from Bradford method and p-nitrophenylphosphate ( $p$ NPP) assay by measuring the absorbance at $595 \mathrm{~nm}$ and $405 \mathrm{~nm}$ respectively in each respective day. The absorbance showed invariable difference in protein concentration and specific activity from starting to final days. Buffers like enzyme dilution and reaction buffers played significant role in VHR enzyme stability and activity. To find out the correct buffer components for carrying out the VHR enzyme assay, several experiments were carried out by using variable constituents in enzyme dilution buffer and reaction buffer. The present study revealed that $3-$ component buffer system without thiol i.e. Dithiothreitol (DTT) or $\beta$-Mercaptoethanol $(\beta$-ME) as a reaction buffer and 2- $N$-morpholino ethanesulfonic acid (MES) buffer with DTT as an enzyme dilution buffer demonstrated invariably different in the stability throughout the experiment.
\end{abstract}

Key words: dilution buffer, dual specific phosphatase, reaction buffer, stability, and VHR enzyme

\section{Introduction}

A variety of cellular functions is governed by a process called protein tyrosine phosphorylation (Kuban et al. 2010, Walton \& Dixon 1993). Due to the interaction between Protein Tyrosine Phosphatases (PTP) and Protein Tyrosine Kinases (PTK), the dynamic balance of tyrosine phosphorylation is possible (Hunter 1989, Alonso et al. 2004, Nicholas 2003). Disturbance in maintaining the dynamic balance can result in cancer and other diseases like diabetes etc (Hunter 1989, Charbonneau \& Tonka 1992). The role of PTP and PTK in the process of cell growth, proliferation, oncogenic transformation, and cell cycle regulation is remarkable. The prototypical member of the dual specific phosphatase (DUSP) group (Amand et al. 2014), VHR dephosphorylates preferably phosphotyrosine residue (Xiao et al. 2013). Positively charged crevices near the active site may explain the enzyme's preference for substrates with two phosphorylated residues. The lack of specific contacts to the aromatic moiety of the phosphotyrosine as well as the shallower depth of VHR's active site likely explains VHR's weak activity toward dephosphorylating phosphothreonine residues (Maria et al. 2002). DUSPs regulate mitogenic signal transduction and control the cell cycle. VHR is isolated from human fibroblasts by Ishibashi et al. (1992). Over expression of VHR enzyme localized in the nucleus brings a key role in cellular proliferation and senescence triggering for the onset of human cervical cancer cells (Panico \& Forti 2013, Wu et al. 2009). 
Correct selection of the required ingredients in the reaction buffer and enzyme dilution buffer is really meaningful to the $p$ NPP and Bradford assay. Wrong choice of these constituents in the buffers causes drastic diminishing of specific activity. In this work several trials were performed by taking MES buffer with DTT or $\beta$-ME as enzyme dilution buffer and 3 -component buffer with DTT or $\beta$-ME as reaction buffer and MES buffer with or without thiol (DTT, $\beta$-ME) as an enzyme dilution buffer as well as reaction buffer. Storing VHR enzyme mandatorily at $-20{ }^{\circ} \mathrm{C}$ (Rahmouni et al. 2006) is cumbersome for those labs lacking $-20{ }^{\circ} \mathrm{C}$ refrigerators. If the enzyme can be stored at higher temperature like $4{ }^{\circ} \mathrm{C}$, the enzyme related works make easier and also becomes a novelty of this research article.

\section{Methodology}

The strain BL21DE3 (isolated from human fibroblast) of VHR gene was inserted in $E$. Coli by the pET-21A vector. A loopful of $E$. coli strain harbouring pET-21AVHR( from glycerol stock) was transferred into a hard glass test tube containing $6 \mathrm{ml}$ of sterilized LB medium containing $30 \mu \mathrm{l}$ of Ampicillin $(10 \mathrm{mg} / \mathrm{ml})$ was added to the LB medium. The culture medium was incubated in a shaking incubator at $37{ }^{\circ} \mathrm{C}$, and at 250 rotations per minute (rpm). Two $\mathrm{ml}$ of the overnight cultured medium was added to $200 \mathrm{ml}$ of $\mathrm{LB}$ medium containing $400 \mu \mathrm{l}$ of Ampicillin $(50 \mathrm{mg} / \mathrm{ml})$ and incubated in shaking incubator at $37{ }^{\circ} \mathrm{C}$ and $250 \mathrm{rpm}$. Optical density (OD) was checked at absorbance 590 $\mathrm{nm}$ at different intervals of time till OD becomes 0.6. Then $200 \mu \mathrm{l}$ of $950 \mathrm{mg} / \mathrm{ml}$ Isopropyl $\beta$-D-1thiogalactopyranoside (IPTG) was added to the inoculated solution and incubated at $37{ }^{\circ} \mathrm{C}$ in shaking incubator with agitation of $250 \mathrm{rpm}$ for about 6 hours. Then the culture solution was kept on ice for 15 mins. The cold solution was centrifuged at $4^{\circ} \mathrm{C}$ and 1000 rpm for 15 mins. Supernatant was discarded and 2.4 $\mathrm{ml}$ of the buffer A (50 mM HEPES, 5.0 mM EDTA, $\mathrm{pH} 7.0)$ and $130 \mu \mathrm{l}$ of $95 \mathrm{mg} / \mathrm{ml}$ Lysozyme were added to the cell pellets. Freezing in liquid nitrogen and thawing in a palm were performed three times. 13.3 $\mu \mathrm{l}$ of $1 \mathrm{M} \mathrm{MgCl}_{2}$ and $7 \mu \mathrm{l}$ of $16 \mathrm{mg} / \mathrm{ml}$ DNase I were added and incubated in a shaking incubator at $30{ }^{\circ} \mathrm{C}$ with constant agitation ( $250 \mathrm{rpm}$ ) for $30 \mathrm{mins}$. To this solution, $67 \mu \mathrm{l}$ of $0.4 \mathrm{M}$ EDTA (pH 8) and $160 \mu \mathrm{l}$ of $10 \%$ Triton $\times 100$ were added and centrifuged at $4{ }^{\circ} \mathrm{C}$, $1000 \mathrm{rpm}$ for $30 \mathrm{mins}$. Finally, the supernatant was collected in an eppendorf tube ( $500 \mu \mathrm{L}$ in each tube), frozen in liq. nitrogen and stored at $-50{ }^{\circ} \mathrm{C}$. Thus obtained solution was used as a crude VHR enzyme. Protein concentration was calculated from Bradford assay graph and then specific activity was computed.

\section{Purification of crude VHR enzyme}

The crude VHR enzyme was purified by a column chromatography. The column was loaded up to $8 \mathrm{~cm}$ by resin (SP Sephadex C-50, Pharmacia LKB, Biotechnology AB, and Uppsala, Sweden) in MES buffer. The crude VHR enzyme was diluted in 10 times in MES buffer ( $\mathrm{pH}$ 6). The diluted VHR enzyme was loaded to the column by $1 \mathrm{ml}$ each time and eluted by several concentrations $(0.2 \mathrm{mM}, 0.5 \mathrm{mM}, 1 \mathrm{mM}, 1.25$ $\mathrm{mM} 1.5 \mathrm{mM}, 1.75 \mathrm{mM}, 2.0 \mathrm{mM}, 2.25 \mathrm{mM}, 2.5 \mathrm{mM}$, $2.75 \mathrm{mM}$ and $3 \mathrm{mM}$ ) of $\mathrm{NaCl}$ in MES. Eluate obtained from different concentrated salt solution was collected separately in a tube. Protein concentration and specific activity of each tube were computed. The tubes containing comparatively high specific activity were loaded in Millipore minicolumn (10,000MWCO, 500 $\mu \mathrm{l}$, Millipore Corporation, Bedford, MA) and centrifuged at $4{ }^{\circ} \mathrm{C}, 4000 \mathrm{rpm}$, and $10 \mathrm{mins}$ to reduce volume. Eventually, protein concentration and specific activity of the concentrated enzyme were measured by Bradford and $p$ NPP assays respectively.

\section{Protein estimation}

Protein concentration was measured by Bradford method (Noble \& Bailey 2009). $1 \mathrm{ml}$ of Bradford reagent was taken in two different eppendorf tube and $4 \mu \mathrm{l}$ and $5 \mu \mathrm{l}$ of E/10 D (E/10D is the 10-fold diluted crude lysate in buffer A: $50 \mathrm{mM}$ Hepes, $5 \mathrm{mM}$ EDTA, $2 \mathrm{mM}$ DTT, pH 7.0) crude lysate (diluted in buffer A) was added in two different tubes. The mixture of E/10 D crude enzyme (diluted in buffer A) was kept at room temperature for 10 minutes. Then the absorbance was measured at $595 \mathrm{~nm}$ separately.

\section{$p$ NPP assay}

VHR enzyme activity was determined by $p$ NPP (Luechapanichkul et al. 2013). Each of two mixtures containing $30 \mu \mathrm{l}$ of $\mathrm{H}_{2} \mathrm{O}, 10 \mu \mathrm{l}$ of $5 \times$ acetate buffer, 5 $\mu \mathrm{l}$ of $\mathrm{E} / 10 \mathrm{D}(\mathrm{E} / 10 \mathrm{D}$ is the 10 -fold diluted crude lysate in buffer A (50 mM Hepes, $5 \mathrm{mM}$ EDTA, 2mM DTT, $\mathrm{pH}$ 7.0) crude enzyme and $5 \mu \mathrm{l}$ of $200 \mathrm{mM} p$ NPP was kept at $30{ }^{\circ} \mathrm{C}$. One of the two mixtures was quenched by $950 \mu \mathrm{l}$ of $0.5 \mathrm{M} \mathrm{NaOH}$ in $1 \mathrm{~min}$ and another in 2 mins. The absorbance was measured at $405 \mathrm{~nm}$ separately. 


\section{Optimization of enzyme dilution and reaction buffer \\ MES buffer as enzyme dil. buffer ( $w /$ DTT) as well as reaction buffer (w/ or w/o DTT)}

For this experiment, MES buffer pH 6 (MES $20 \mathrm{mM}$, EDTA $1 \mathrm{mM}$ ) was used as both enzyme dilution buffer and reaction buffer. A reaction mixture contained 525 $\mu \mathrm{l}$ of $\mathrm{H}_{2} \mathrm{O}, 210 \mu \mathrm{l}$ of reaction buffer (MES buffer $\mathrm{pH}$ 6 with DTT), $105 \mu \mathrm{l} 2.3 \mathrm{mg} / \mathrm{ml}$ of E/10 D VHR enzyme (diluted in MES buffer). Then $45 \mu$ lof aliquot of the reaction mixture was incubated at $30^{\circ} \mathrm{C}$ for the given time periods (on the basis of $\mathrm{X}$-axis) followed by the addition of $5 \mu \mathrm{l}$ of $20 \mathrm{mM} p \mathrm{NPP}$ and the mixture was incubated at $30{ }^{\circ} \mathrm{C}$ for $3 \mathrm{~min}$. The reaction mixture was quenched with $950 \mu$ of $0.5 \mathrm{M} \mathrm{NaOH}$ and the absorbance was measured at $405 \mathrm{~nm}$. The similar experiment was carried out with reaction buffer contain MES buffer $\mathrm{pH} 6$ with $\beta$-mercaptoethanol and MES buffer $\mathrm{pH} 6$ without DTT respectively.

MES buffer as enzyme dil. buffer (w/ DTT) and 3 comp. buffer (w/or w/o DTT) as reaction buffer

In this experiment, MES buffer as an enzyme dil. buffer and 3 components buffer $\left(\mathrm{CH}_{3} \mathrm{COONa} 50 \mathrm{mM}\right.$, Tris $\mathrm{HCl} 25 \mathrm{mM}$, bis-tris propane $25 \mathrm{mM}$ ) as a reaction buffer were used. The same experimental procedure was followed as mentioned above.

\section{Stability at $4{ }^{\circ} \mathrm{C}$}

Generally, VHR enzyme is stored at $-20{ }^{\circ} \mathrm{C}$. In this study, the viability of the enzyme was determined by storing the enzyme at $4{ }^{\circ} \mathrm{C}$ for ten days. Then the protein concentration and specific activity of the enzyme were determined from first day of storage to the tenth day. In our attempt, the viability of the enzyme was testified by storing at $4{ }^{\circ} \mathrm{C}$. The experiment was carried out for ten days. Computation of the protein concentration and specific activity were determined by Bradford and $p$ NPP assays as mentioned above.

\section{Results and Discussion}

Buffers play important roles in carrying out enzyme assay. Here we tried both buffers i.e. enzyme dilution and reaction buffers varying in ingredients to check the stability of an enzyme. The first experiment was carried out by taking MES buffer with DTT as enzyme dilution buffer and MES buffer with or without thiol (DTT/ $\beta$-Mercaptoethanol) as reaction buffer. To find out the effect of reaction buffer, three different sets of reactions were performed. In all three experiments, MES buffer with DTT as enzyme dilution buffer and the components of reaction buffer was varied. In the first case, MES buffer with DTT was used as reaction buffer (Fig. 1 - ). In the second case, MES buffer with $\hat{a}$-mercaptoethanol was used as reaction buffer (Fig. 1 - ). Consequently, MES buffer without thiol as reaction were taken to carry out the third trail (Fig. $1 \boldsymbol{A}$ ). Each of the above three experiments was triplicated. From Fig. 1, it was revealed that the absorbance was decreasing from zero time to 90 mins in all the experiments. Among the three, the first trail showed relatively less decrease in the absorbance than the second trial than the third trial. From the experiment, it was revealed that the selection of variable constituents in both buffers was misleading i.e. the buffer systems were not suitable for conducting the enzyme assay.

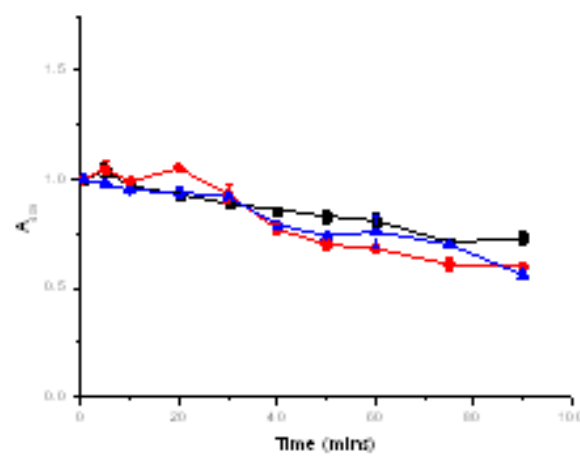

Fig. 1. Stability of VHR with DTT in enzyme dil. buffer and with or without thiol in reaction buffer.

(Note: A on y-axis stands for absorbance) The symbol ( - indicates DTT in both enzyme dilution buffer as well as reaction buffer, $(\bullet$ ) symbolizes DTT in enzyme dil. buffer and â-me ptoethanol in reaction buffer and the symbol ( $\boldsymbol{A}$ denotes DTT in enzyme dilution buffer but no D'ı 1/ $\beta$-ME in reaction buffer (each experiment was carried out in triplicates).

In the second experiment (Fig. 2), a set of trails was done by taking MES buffer with DTT as enzyme dilution buffer and 3 component buffer with or without DTT as reaction buffer. For all three sets of the trails, enzyme dilution buffer contained DTT. In case of reaction buffer, DTT was added for the first trail, $\beta$-mercaptoethanol for the second trail, and without 
thiol for the third trial. Each trail was conducted in triplicates. While comparing the absorbance of all three trails, the third trail (Fig. 2 showed invariably different from starting to the end. The remaining two trails indicated that the absorbance was irrelevant (variably different) with increasing time. Hence, while using VHR enzyme for a certain purpose, it is suggested that MES buffer with DTT as enzyme dilution buffer and 3-component buffer without thiol as reaction buffer are to be used.

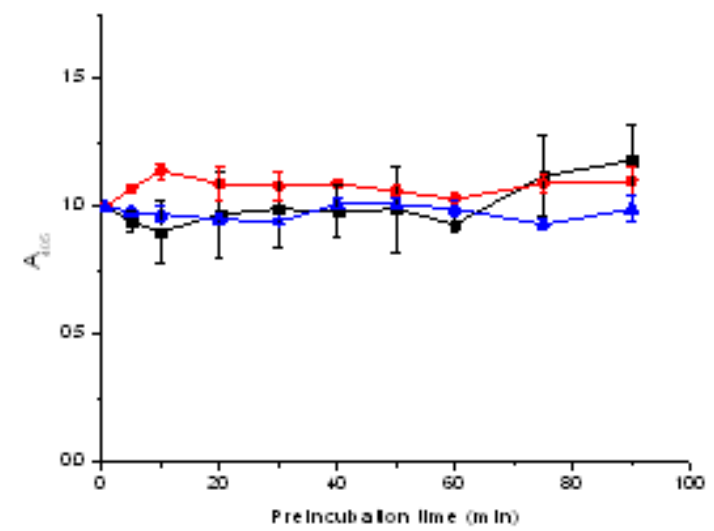

Fig. 2. Stability with MES buffer (w/DTT) as enzyme dil. buffer and 3 component buffer (w/or w/o DTT) as reaction buffer.

(Note: A on y-axis s(Note: A on y-axis stands for absorbance) The symbol ( - indicates DTT in both enzyme dil. buffer as well as reaction buffer, ( symbolizes DTT in enzyme dil. buffer and mercaptoethanol in reaction buffer and the symbol ( $\boldsymbol{\wedge}$ denotes DTT in enzyme dilution buffer but no DTT/ $\beta$-ME in reaction buffer (each experiment was performed in triplicate).

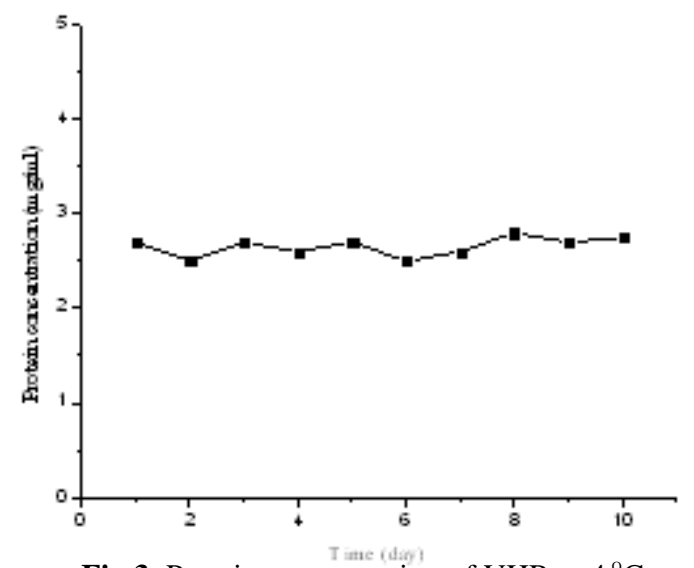

Fig.3. Protein concentration of VHR at $4{ }^{\circ} \mathrm{C}$
An experiment was also carried out to testify the stability of VHR enzyme at $4{ }^{\circ} \mathrm{C}$ where protein concentration and specific activity were measured. For this experiment, the enzyme has been stored at $4{ }^{\circ} \mathrm{C}$. Protein concentration and specific activity were measured every day by Bradford assay and $p$ NPP as mentioned above. The experiment was continued for ten consecutive days. Fig 3 revealed that the protein concentration remained nearly consistent throughout the experiment. From Fig 4, the specific activity of the VHR enzyme looked nearly the same throughout the 10 days experiments. So, it is concluded that the VHR enzyme could be stored at $4{ }^{\circ} \mathrm{C}$ for a month.

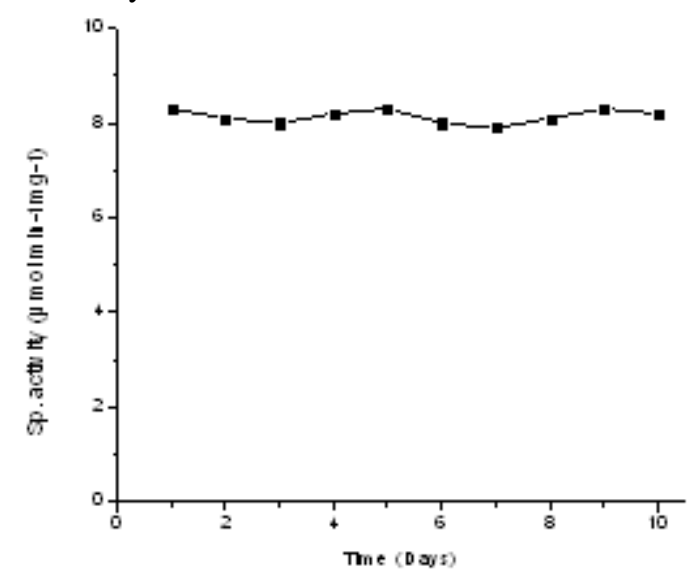

Fig.4. Specific activity of VHR at $4{ }^{x \%} \mathrm{C}$

\section{Acknowledgements}

The author greatly acknowledges Protein Chemistry Lab, Inha University, South Korea for supporting of this research.

\section{References}

Amand, M., C. Erpicum, K. Bajou, F.Cerignoli, S. Blacher, M. Martin, F. Dequiedt, P. Drion, P. Singh, T. Zurashvili, M. Vandereyken, L. Musumeci, T. Mustelin, M. Moutschen, C. Gilles, A. Noel and S. Rahmouni. 2014. DUSP3/VHR is a pro-angiogenic atypical dual-specificity phosphatase. Molecular Cancer 13: 108.

Alonso, P. A., J. Sasin, N. Bottini, I. Friedberg, A. Osterman, A. Godzik, T. Hunter, J. Dixon and T. Mustelin. 2004. Protein tyrosine phosphatases review in the human genome. Cell 117: 699-711.

Charbonneau, H. and N. K. Tonka. 1992. 1002 protein phosphatases?. Annu. Rev. Cell Biol. 8: 463-493.

Hunter, T. 1989a. Protein-tyrosine phosphatase: the other side of the coin. Cell 58(6): 1013-1016. 
Deegendra Khadka/Optimization of Enzyme Dilution Buffer..

Hunter, T. 1989b. Oncogene products in the cytoplasm: the protein kinases. In: Oncogenes and Molecular Origins of Cancer ( Ed. RA Weinberg ). Pp. 147-173.

Ishibashi, T., D. P. Bottaro, A. Chan, T. Miki and S. A. Aaronson. 1992. Expression cloning of a human dualspecificity phosphatase. Proc. Natl. Acad. Sci. USA 89: $12170-12174$.

Kuban, J. A., M. Górska, A Debicki, U. Popowska, N. Knap and M. WoŸniak. 2010. Protein tyrosine phosphatases-endogenous markers of oxidative stress. Postepy Biochem. 56 (26): 269-273.

Luechapanichkul, R., X. Chen, H. A. Taha, S. Vyas, X. Guan, M. A. Freitas, C. M. Hadad, and D. Pei. 2013. Assay specificity profiling of dual specificity phosphatase vaccinia VH1-related (VHR) reveals two distinct substrate binding modes. The Journal of Biological Chemistry 288 (9): 6498 -6510.

Maria, A. S., L. T. Jacob, E. R. Adrian, G. T. Kirk and M. D. John. 2002. Structural basis of the recognition of bisphosphorylated MAP kinase peptide by human VHR protein phosphatase. Biochemistry 41 (9): 3009 3017.

Nicholas, K. T. 2003. PTP1B: From the sidelines to the front lines!. FEBS Letters 546: 140-148.
Noble, J .E., and M. J. A. Bailey. 2009. Quantitation of protein. Methods Enzymol. 463: 73-95.

Panico, K. and F. L. Forti. 2013. Proteomic, cellular, and network analyses reveal new DUSP3 interactions with nucleolar proteins in HeLa cells J. Proteome Res. 12 (12): 5851-5866.

Rahmouni, S., F. Cerignoli, A. Alonso, T. Tsutji, R. Henkens, C. Zhu, C. Moutschen, M. Louis-dit-Sully, W. Jiang and T. Mustelin. 2006. Loss of the VHR dual-specific phosphatase causes cell-cycle arrest and senescence. Nat. Cell Biol. 8 (5): 524-531.

Walton, K. M. and J. E. Dixon. 1993. Protein tyrosine phosphatase. Annu. Rev. Biochem 62: 101-120.

Wu, S., Sofie V., S. Rahmouni, A. V. Miletic, T. Vang, J. Vazquez-Rodriguez, F. Cerignoli, Y. Arimura, S. Williams, T. Hayes, M. Moutschen, S. Vasile, M. Pellecchia, T. Mustelin, and L. Tautz. 2009. Multidentate small-molecule inhibitors of Vaccinia H1-related (VHR) phosphatase decrease proliferation of cervix cancer cells. J. Med. Chem. 52 (21): 6716-6723.

Xiao, W., R. Luechapanichkul, Y. Zhai, and D. Pei. 2013. Specificity profiling of protein phosphatases toward phosphoseryl and Phosphothreonyl peptides. J. Am. Chem. Soc., 135 : 9760-9767. 
Nepal Journal of Science and Technology Vol. 15, No.2 (2014) 117-122 